\title{
Cova des Pas de Vallgornera, (Mallorca, Spain): history of exploration and cave description
}

\author{
Antoni Merino ${ }^{1 *}$, Antoni Mulet ${ }^{1}$, Guiem Mulet ${ }^{1}$, Antoni Croix ${ }^{2}$, Anders Kristofersson ${ }^{2}$, Francesc Gràcia ${ }^{3,4}$, \\ and Miquel A. Perelló ${ }^{3}$
}

${ }^{1}$ Grup Espeleològic de Llubí. Federació Balear d'Espeleologia. c/Uruguai s/n, Palma Arena, 07010 Palma, Illes Balears, Spain

${ }^{2}$ Secció d'Espeleologia Voltors-OJE. Federació Balear d'Espeleologia. c/Uruguai s/n, Palma Arena, 07010 Palma, Illes Balears, Spain

${ }^{3}$ Grup Nord de Mallorca. Federació Balear d'Espeleologia. c/Uruguai s/n, Palma Arena, 07010 Palma, Illes Balears, Spain

${ }^{4}$ Departament de Ciències de la Terra, Universitat de les Illes Balears, Ctra. Valldemossa km 7,5, 07122 Palma, Illes Balears, Spain

\begin{abstract}
The Cova des Pas de Vallgornera lies in the Llucmajor municipality, in southern Mallorca, and is the longest cave in the Balearic Islands. Currently its surveyed length is over $74,000 \mathrm{~m}$, including more than $17,000 \mathrm{~m}$ of underwater extensions. The cave was discovered accidentally in 1968, but it was in 2004 when a major breakthrough shed light on its real extension and importance. The cave roughly shows two tiers of passages, apart from the underwater extensions, the first one is between 7 and $11 \mathrm{~m}$ above the mean sea level, the second one is about at the water table level. The importance of the cave is not only related to its extension, but also to the presence of a wide variety of speleothems and outstanding solutional morphologies that evidence a complex evolution. The cave is under the protection of Conselleria de Medi Ambient, Govern de les Illes Balears (the Regional Environmental Authority) and was declared Site of Community Importance, within the Natura 2000 Network.
\end{abstract}

Keywords: Cova des Pas de Vallgornera; Mallorca; history; description; exploration

Received 6 October 2013; Revised 16 December 2013; Accepted 28 February 2014

Citation: $\quad$ Merino A., Mulet A., Mulet G., Croix A., Kristofersson A., Gràcia, F. and Perello M.A., 2014. Cova des Pas de Vallgornera, (Mallorca, Spain): history of exploration and cave description. International Journal of Speleology, 43 (2), 95-104. Tampa, FL (USA) ISSN 0392-6672 http://dx.doi.org/10.5038/1827-806X.43.2.1

\section{INTRODUCTION}

The cave was discovered on April the $26^{\text {th }}, 1968$ while drilling a cesspit for the sewage of a hotel that was being built in the area. During the following days, a representative from the Llucmajor local Council along with a photographer undertook the first visit to the cave. Two days later, the news about the discovery were published on the front page of the Diario de Mallorca newspaper.

Local caving groups: Centro de Actividades Espeleológicas, Grup Espeleològic EST and Speleo Club Mallorca began the exploration of the cave. Later, in 1970, a group of Belgian cavers from Groupe Speleo Namur Ciney undertook the first survey of the cave. Between 1991 and 1992, cavers from Grup Espeleològic EST and Secció d'espeleologia de l'ANEM completely explored and surveyed the cave, yielding about $2 \mathrm{~km}$ of cave passages. In 1994 an important breakthrough came when cavers from Grup Espeleologic EST enlarged a tight passage that led the explorers to new galleries and chambers. The survey and exploration of the newly discovered part started in 1994 and was completed in 1999; at that time the cave was $6.4 \mathrm{~km}$ long including some extensive pools. From 2002 members of Grup Espeleo Llubí and Secció d'Espeleologia de l'ANEM faced the challenge of investigating a slight draught of air at one remote chamber. In 2004 Grup Espeleo Llubí achieved a major breakthrough when a draughting slot was discovered, leading the explorers into the biggest known chamber in the cave so far. The discovery fueled the fires and the cavers begun the exploration of a maze of passageways and chambers. Along the way, cavers from Secció d'espeleologia de Voltors and Grup Espeleologic EST joined the team that is still exploring, surveying and studying this impressive and complex cave; important underwater extensions are currently being explored and surveyed by cave divers from Grup Nord de Mallorca and lately also Grup Espeleo Llubí.

The cave is located in the Llucmajor municipality in southern Mallorca, being developed in the natural area of Migjorn (coordinates UTM/WGS84, 489120; 4.357.510). A great deal of galleries and chambers lies beneath the Vallgornera housing estate (east of Cala 
Pi), while the northernmost sections are developed under farm land (Fig. 1). This littoral karstic region is formed by a tabular platform built up by a TortonianMessinian reefal limestones sequence. With over $74,000 \mathrm{~m}$ of surveyed passages and chambers, it is the longest cave of the island and one of the most important in Spain (Fig. 2).

The cave is formed by a series of breakdown chambers which are interconnected with each other by a network of passages situated at different levels. In spite of the labyrinthine pattern of the cavern, it is possible to recognize several rectilinear main passages that run relatively parallel from SW to NE. Some of them are close to one kilometre in length, being structurally controlled by major joints. The lower part of the cave is occupied by brackish water pools, whose surfaces rise or fall with tidal fluctuations of the sea level. The system has two tiers of passageways clearly

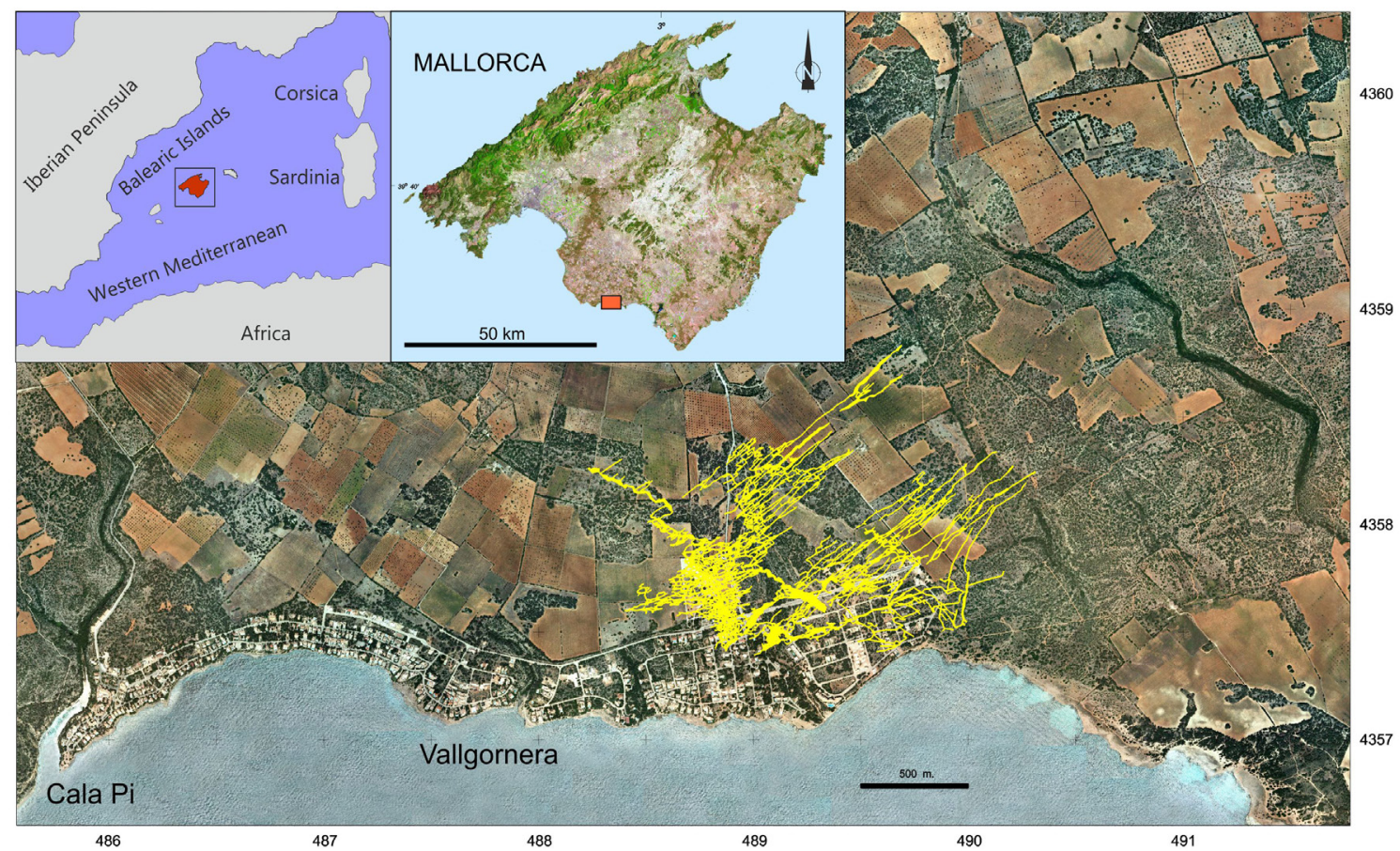

Fig. 1. a) Location of Mallorca Island within the Western Mediterranean sea; b) The red square shows the situation of the cave in the Southern region of Migjorn; c) Plan pattern of Cova des Pas de Vallgornera overlapping an aerial view of the area (ortophoto PNOA-2008).

\section{COVA DES PAS DE VALLGORNERA (LLUCMAJOR)}

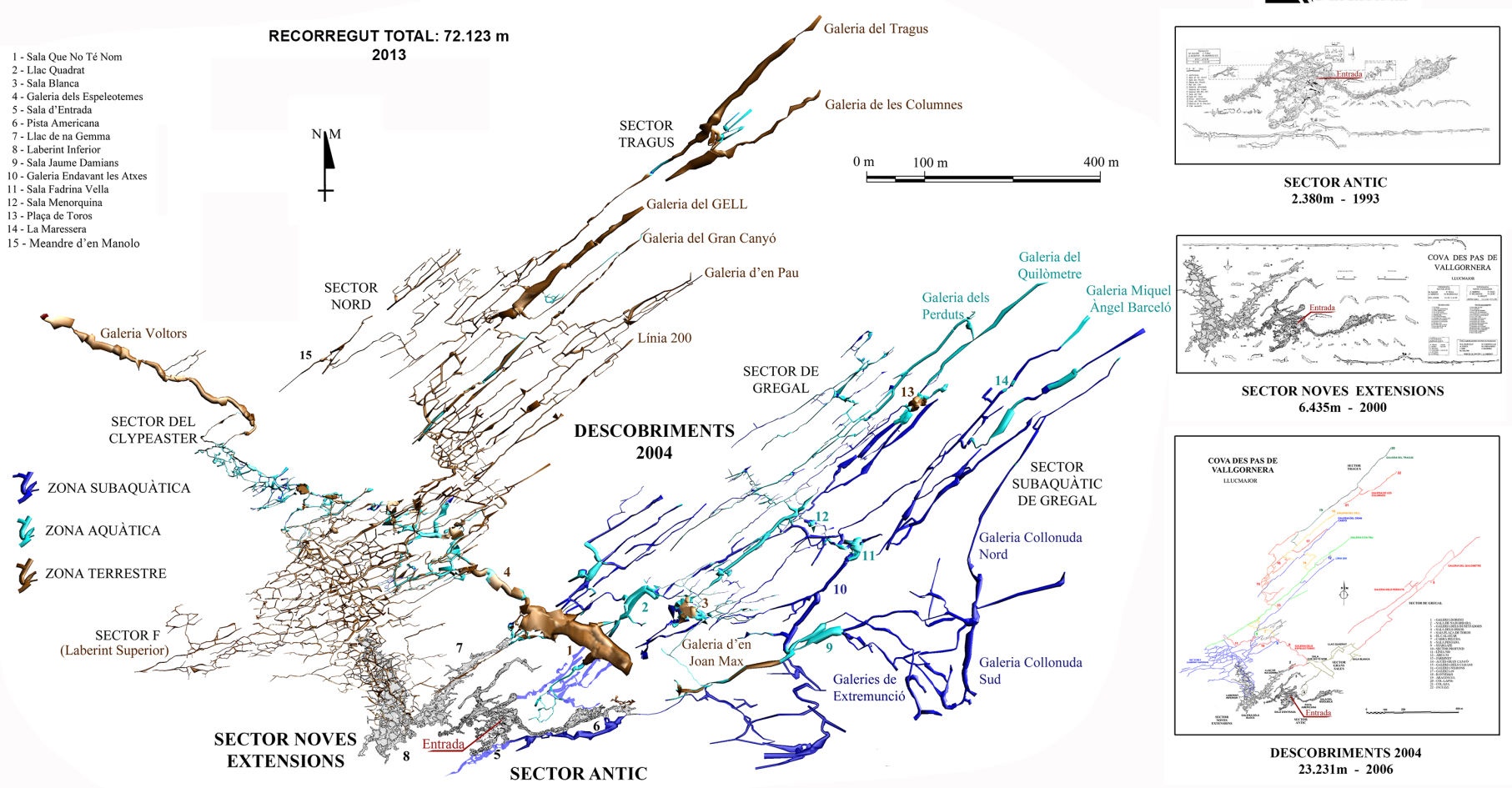

Fig. 2. Map of the cave with the main sectors described. While the Sector Antic and Noves Extensions contain longitudinal sections, there is a lack of them in Descobriments 2004 due to the impossibility to construct a reasonable longitudinal section in this maze of long and in general, narrow galleries. 
differentiated: the first one is located approximately at the current water table level, whereas the second one is situated between 7 and $11 \mathrm{~m}$ above the brackish waters. Moreover, underwater explorations have revealed the presence of a vast series of galleries below the present-day water table level.

The importance of the cave is not only related to the extension attained by the cave, but also the finding of rare types of speleothems, fossil remains, Quaternary sand deposits, and conspicuous corrosion morphologies. All this has prompted the local authorities (Conselleria de Medi Ambient, Govern de les Illes Balears) to protect the cave and access to it is now severely restricted.

\section{HISTORY}

Exploration has taken place in three different stages, corresponding to those of the breakthroughs.

\section{Sector Antic (1968-1992)}

Between 1968 and 1969 local caving clubs, Centro de Actividades Espeleológicas, Grup Espeleològic EST and Speleo Club Mallorca, began the explorations (Fig. 3). Subsequently, the hotel propietor, a Belgian citizen at that time, contacted a group of Belgian cavers from Groupe Spéléo Namur-Ciney and commissioned them to explore and survey the cave with the aim of considering the possibility of opening it as a show-cave (Collignon, 1982). However the report, based on that information, was negative and plans were abandoned.

As a result of a meeting held between cavers from Grup Espeleològic EST and Secció d'Espeleologia de l'ANEM in 1990, it was decided to begin a comprehensive survey and study of the cave. The task began in 1991 and was finished by the end of 1992, yielding about 2 kilometres of surveyed passages, the so-called Sector Antic (Merino, 1993). The exploration of underwater passages began in 1991 when divers from Cas Triton explored and surveyed the submerged galleries located in this sector.

\section{Noves Extensions (1994-1999)}

On July the $2^{\text {nd }} 1994$, an important breakthrough came when, Miquel Barceló and Pedro Riera from Grup Espeleologic EST enlarged a tight passage that

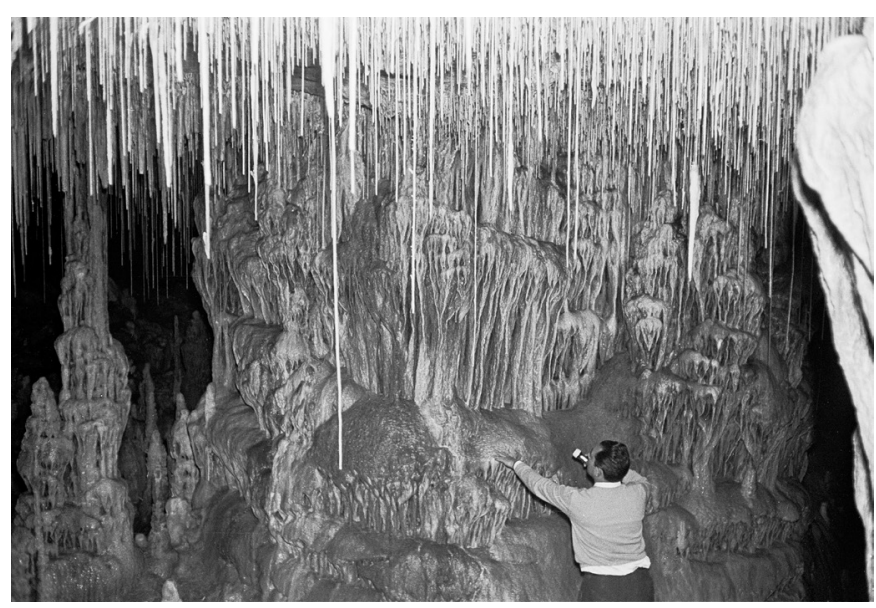

Fig.3. One of the first photos taken at Sala d'Entrada while exploring the cave on the earliest days (photo by Magí Clar). led the explorers into a series of new galleries and chambers (Fig. 2). Early in the winter of that year, the survey of the new discoveries started and continued for some months in 1995, but some problems within the survey team and later the sealing of the cave entrance by the local Authority caused a temporary interruption to the work in the cave.

After several meetings held between the Federacio Balear d'Espeleologia and the Conselleria de Medi Ambient along with the Llucmajor Council, the issue was addressed and the decision of protecting the cave was taken. A small locked and gated hut was built over the entrance. Eventually, the last leg of the survey task was restarted on July the $4^{\text {th }}, 1998$, being finished on November the $27^{\text {th }}, 1999$. Furthermore, between 1995 and 2001 members of Grup Nord de Mallorca carried out several visits to the cave exploring and surveying submerged passages of the fresh discovered galleries. At that time the cave was $6.4 \mathrm{~km}$ long including some extensive brackish pools. That sector was named Noves Extensions (Merino, 2000).

\section{Descobriments 2004 (2004-2013)}

Cavers from Grup Espeleològic Llubi (GELL) and Secció d'Espeleologia de 1'ANEM kept visiting the cave with the aim, among others, of continuing studies at the remote spots of the cavern. From 2002 exploration was focused on an area extending from the innermost part of Llac de Na Gemma and Sala de Na Bàrbara (in the Noves Extensions sector), where a slight draught fluctuated in intensity and direction. Because of that, a thorough control of the air pressure and water table level changes were established. As a first result, some new narrow galleries and a small chamber with a pond were found at the northern section of Sala de Na Bàrbara.

2004 was an important year in the history of Cova des Pas de Vallgornera. After a massive series of explorations that took place throughout 2003 and the beginning of 2004, in June it was possible to follow the air flow. Consequently, a draughting slot was found and widened by the explorers who gained access to a series of small passages and tight rifts that seemed to get narrower preventing them from progressing.

After spending several hours exploring between boulders, Guiem Mulet squeezed through a tight slot that led him to the beginning of the Sala Que No Té Nom. Speechless, he crawled back to join Toni Mulet and Tony Merino to tell them of the fresh discovery. The three highly excited cavers explored the vast chamber, the largest found in the cave so far, hardly believing what lay beyond.

Since then exploration and survey tasks have been taking place without a break. With the ambitious aim of fulfilling the project, different local caving clubs, including Secció d'Espeleologia Voltors, Grup Espeleològic EST, and cave divers from Grup Nord de Mallorca worked together with Grup Espeleològic Llubí. Cova des Pas de Vallgornera undoubtedly became one of the most jaw-dropping cave in Spain, due to its surveyed length over 74,000 m so far (Merino et al., 2006, 2007, 2008, 2009, 2011). In 2007 cave divers from Grup Nord de Mallorca joined in and started the exploration of the 
underwater extensions situated in the newly discovered sector, called Descobriments 2004. The group of divers found considerable prolongations with long galleries and chambers that present important accumulation of sediments, well-decorated passages, etc. In just three years, from 2007 to 2009, the group devoted more than 140 visits to the cave, exploring and surveying more than $10,000 \mathrm{~m}$ of underwater passages, photo documenting their discoveries (Gràcia et al., 2009). At the beginning of 2012 cave divers from Grup Espeleo Llubí also started to explore and survey different submerged areas. Since the first exploration in the Descobriments 2004 series and because of the great deal of passages and their complexity, the need to set up an underground camp became clear. The purpose was to be able to spend two or more days in the cave and at the same time improving the well-deserved rest period. As a result of the cave unique features and the need of swimming across long ponds cavers had to face a logistic problem that eventually was overcome. Once all the equipment had been hauled to a previous chosen spot at the Sala Que No Té Nom, the camp was definitely established (Fig. 4).

As far as the survey task, new challenges were taken up; the main problem was how to keep surveying without losing the broad overview on the already mapped labyrinth of passages and chambers. The pencil-and-notebook traditional system along with notes and sketches became ineffective due to the cave's size and complexity. Therefore the use of PDA's and lap-tops was undertaken, besides the disto laser measuring device brought about a significant change to the routine, not only because of the higher level of performance achieved, but mainly for conservation reasons. Those devices greatly simplified the instrument readings and at the same time the disto laser prevented cavers from being too close to formations. Nevertheless, when surveying while swimming in partially drowned passages or extensive ponds most of the electronic gadgets were useless; then the pencil, water-proof notebook, and tape were again required.

\section{DESCRIPTION OF THE CAVE}

The cave can be clearly divided into three welldifferentiated units, related to the temporal evolution of

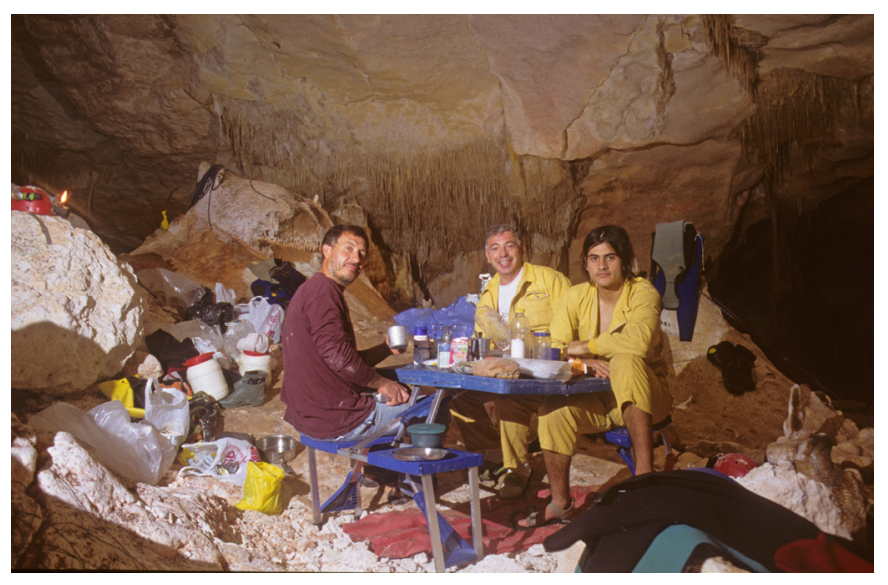

Fig. 4. During the early stages of exploration at Descobriments 2004, a camp was set at Sala Que No Té Nom in order to make easier the long exploration week-ends easier (photo by Tony Merino). the discoveries: the so-called Sector Antic, the Noves Extensions and finally, the Descobriments 2004 series. The connection between these three units corresponds to tight constrictions that previously isolated them, which needed the clearance of some speleothems to allow the exploration. In order to attain a proper description of the cave, up to 10 sectors have been distinguished (Fig. 2) most of them corresponding to individualized sectors within the Descobriments 2004 series.

\section{Sector Antic}

The Sector Antic (Merino, 1993) is formed by a breakdown chamber, Sala d'Entrada, which is gained through the only known entrance to the cave, a 6 metres deep man-made well. Extensive flowstones cover and cement most of the large accumulations of boulders of different sizes that make up the floor. The chamber is lavishly decorated with stalactites, stalagmites and groups of columns that cause a slight compartmentalization. A gour situated to the East side of the chamber shows the way to the Pista Americana, which is reached after negotiating a boulder choke and climbing down a steep slope. The Pista Americana is floored with large boulders and small brackish ponds, up to $5 \mathrm{~m}$ in length, occupy the right-hand side of the passage, which is scarcely decorated. The way leads on and opens into a chamber, Sala del Moonmilk, deriving its name from the abundance of these deposits that covers the area. Close to the end of this uneven, low-roofed chamber, an opening in the floor allows descending through the boulders in Via Max, a passage that contains similar features.

Back to the Sala d'Entrada, and towards the NW sector, a downslope constricted passage gives access to the drowned section of Sector Antic and the galleries that constitute the Noves Extensions (Merino, 2000).

\section{Noves Extensions}

The passages of Noves Extensions sector, located at the current water table elevation, can be divided into two clearly differentiated sectors: the Lakes series and the Lower Maze. The former one contains the impressive pool of Llac de Na Gemma which is more than $200 \mathrm{~m}$ long and constantly varies in width (reaching a maximum of $40 \mathrm{~m}$ ), narrowing towards the end because of flowstones and boulders leading into Sala de na Bàrbara. The first third of Llac de Na Gemma is gorgeously ornamented with soda straw forests and assemblages of stalactites covered in helictites that reach the water table; war club stalactites occur at some points. This richness in formations vanishes in a matter of few meters after which the bare ceiling and walls only show corrosion morphologies. The latter, the Lower Maze, is formed by a framework of small passages whose walls and roof are covered with solutional sculpturings and groups of speleothems (Fig. 5) as it can be clearly seen in Galeria d'Enmig and Galeria de Llevant.

\section{Descobriments 2004}

Finally, the Descobriments 2004 series is where the cave reaches its longer and notable dimensions (Merino et al., 2006, 2007, 2008, 2011). Roughly speaking, the new galleries and chambers discovered 


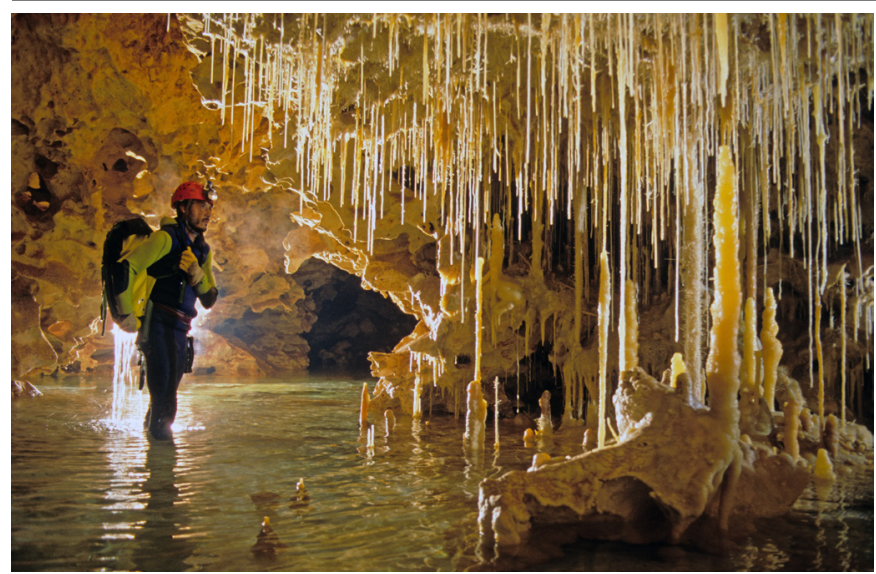

Fig. 5. Common combination of speleothems and corrosion morphologies at the lower maze, in the Noves Extensions series. The brackish water table is present throughout the whole area (photo by Tony Merino).

in Cova des Pas de Vallgornera are neatly organized in two different tiers, besides the underwater extensions. The first one is located at the water table level or slightly above it. At points where the roof and walls have collapsed, passages and chambers of different sizes occur, some of them impressively large, like Sala Que No Té Nom, which has an area exceeding 11,000 square meters. The second, the upper tier, situated between 7 and $11 \mathrm{~m}$ above the water table, is characterized by networks of rectilinear passages creating complex labyrinths (Fig. 6). In these series up to eight new sectors can be distinguished: Sector de les Grans Sales, Sector de Gregal, Sector Subaquàtic de Gregal, Sector F, Sector del Clypeaster, Sector del Tragus, Sector Nord and Sector dels Privilegiats.

\section{Sector de les Grans Sales}

The first one, whose name refers to the great chambers included in it, is located to the northeastern part of Noves Extensions and Sector Antic passages. It consists of an assemblage of breakdown chambers heading in a northwest-southeast direction, ringed by phreatic water pools. Sala Que No Té Nom (Fig. 7) is gained from a subaerial small passage that begins at Sala de Na Bàrbara -the last chamber of Noves Extensions series- or diving from the NE aquatic section of Sector Antic. The existence of large boulders that floor the chambers is the common denominator to all of them. Speleothems are rather scarce and corrosion processes significantly affect some of them. As a consequence of boulder settling, some flowstones that cover the floors, are cracked and broken. Sala Que No Té Nom, with a length of $230 \mathrm{~m}$ and an average width of $46 \mathrm{~m}$, is so far, the largest breakdown chamber in the cave and could be considered the "hub" of the cave from where most of the passages are distributed. The water table is reached at both sides of the chamber's central axis through down slopes composed of rocks and boulders. The Llac Quadrat, which is about $65 \mathrm{~m}$ long and with a maximum width of $20 \mathrm{~m}$, has the same features but is totally drowned by phreatic waters; the bottom of this massive brackish lake is formed by a large accumulation of boulders. This point is the access way to Sala Blanca and to other sectors of the cave (Sector de Gregal and Sector Subaquàtic de Gregal).

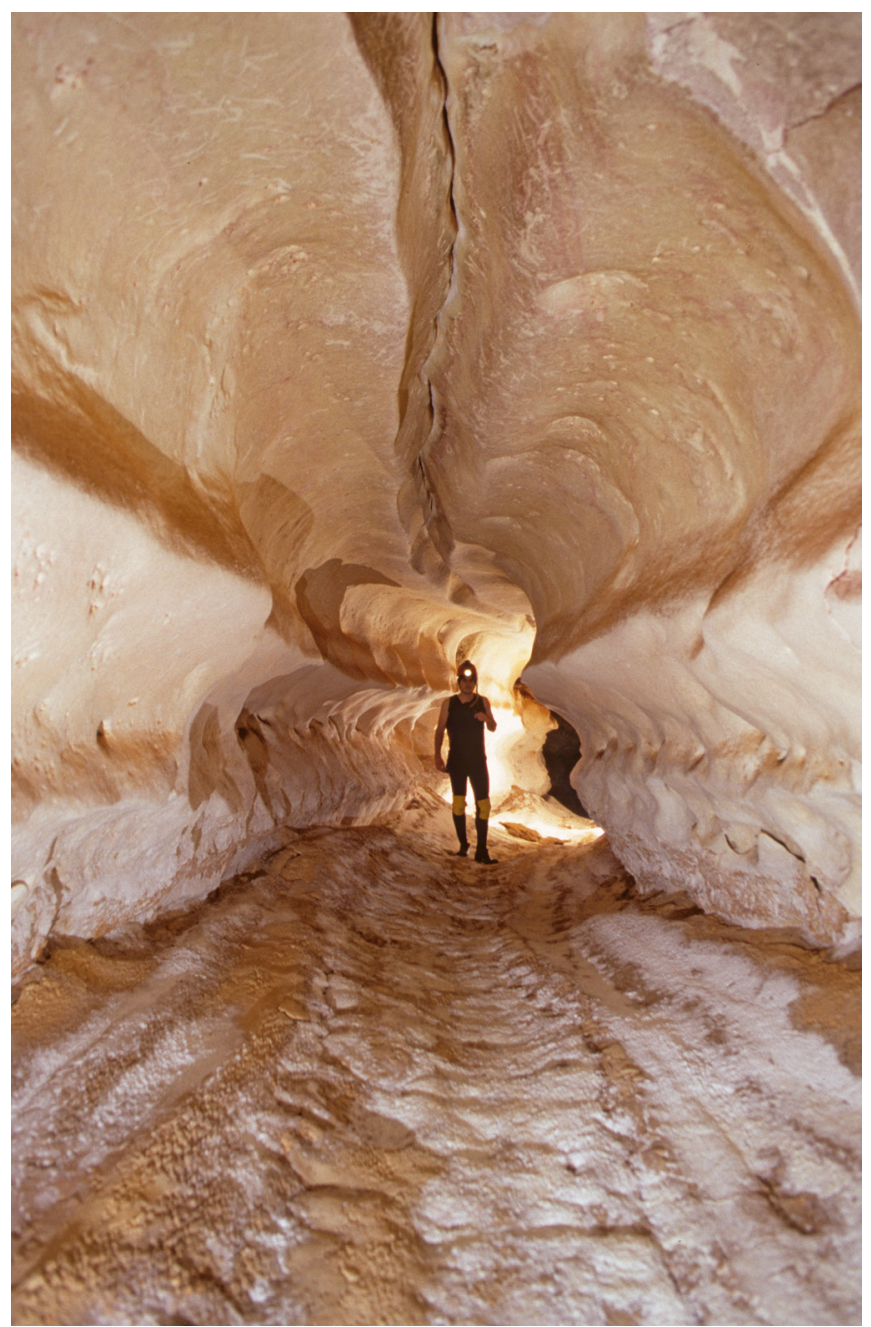

Fig. 6. Galeria d'En Pau, a typical structurally controlled passage located at the upper tier of the cave. The joint controlling the passage is clearly seen in the ceiling (photo by Tony Merino).

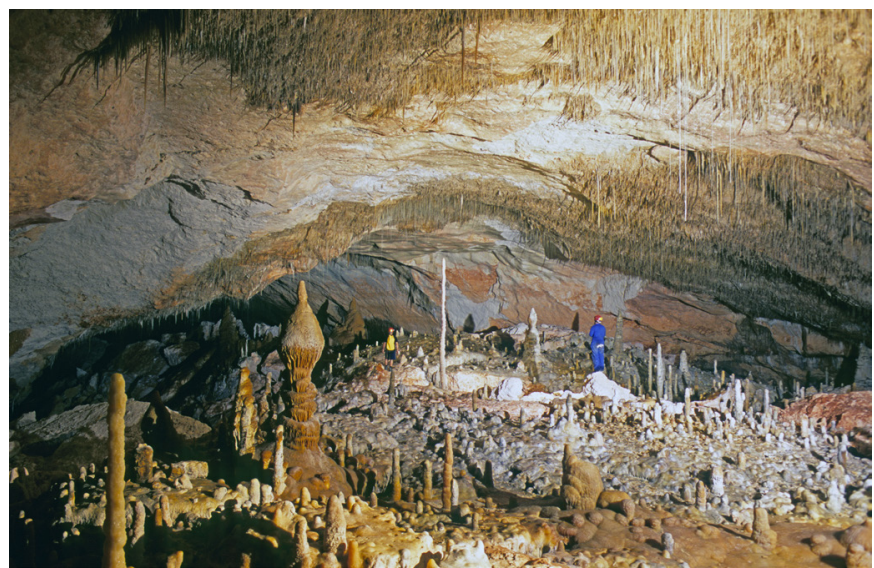

Fig. 7. A view over the massive Sala Que No Té Nom. A large accumulation of boulders floors this breakdown chamber, the presence of the soda straw forest that decorates the ceiling is favoured by the highly porous calcarenite in which the cave is excavated (photo by Tony Merino).

The already described Sala Que No Té Nom continues to the NW through Galeria dels Espeleotemes, which is remarkable for its dimensions and abundance of speleothems Galeria dels Espeleotemes is the connection with the innermost sectors of the cave.

\section{Sector de Gregal and Sector Subaquàtic de Gregal}

These two sectors, located at the water table level or below it, spread out in NE trend from the Sala Que No 
Té Nom and Llac Quadrat area. Both stand out because of their dimensions. In Sector de Gregal some of the most important galleries are Galeria del Quilometre (Fig. 8), with a length of $1000 \mathrm{~m}$, and Galeria dels Perduts which is $750 \mathrm{~m}$ long. The majority of these long passages are flooded by brackish phreatic waters; the large accumulation of boulders, caused by breakdown processes, constantly force cavers to enter and leave water. Abundant solutional ascending grooves and channels are conspicuous on the walls of some parts of these passages. At the same time, along the SE side of this area different collapse chambers are present, like Sala de la Fradina Vella and Sala de la Menorquina. The beginning of the last third of Galeria del Quilometre is marked by another rounded-shape chamber, Plaça de Toros. This breakdown chamber, $40 \mathrm{~m}$ long and $20 \mathrm{~m}$ in width, is formed by a boulders cone rising $8 \mathrm{~m}$ above the water table. Scattered among the main galleries, labyrinths formed by smaller passages occur. Finally, Galeria d'en Navarrete, which is $450 \mathrm{~m}$ in length, must be mentioned, not only because of the abundant corrosion morphologies that cover walls and ceiling, but also for the notable accrual of mud deposits piled up in the middle of the passages.

The underwater sector, Sector Subaquàtic de Gregal, is a massive assemblage of totally flooded passages, with only a few aquatic galleries located around the water table, as well as some breakdown chambers. Its passages reach outstanding length and head in northeast-southwest direction; Galeria Miquel Àngel Barceló, Galeria Grup Nord de Mallorca and Galeria Collonuda must be underlined. The first one is quite parallel to Galeria del Quilòmetre, trending $\mathrm{SW}$ to $\mathrm{NE}$; its width is variable, between 1.5 to $7 \mathrm{~m}$, reaching a depth of $8 \mathrm{~m}$.

Galeria Grup Nord de Mallorca is a structurally controlled passage with a length of $700 \mathrm{~m}$ that ends at a collapsed area where the flat ceiling allows the exposure of marly strata. Along the passage, various types of morphologies are present, corrosion features are prominent while speleothems are scarce.

With a roughly $\mathrm{N}-\mathrm{S}$ trend, Galeria Collonuda is a massive gallery that can be divided into two areas, depending on the passage direction. The first, heading $\mathrm{N}$, is practically deprived of any branches, while the

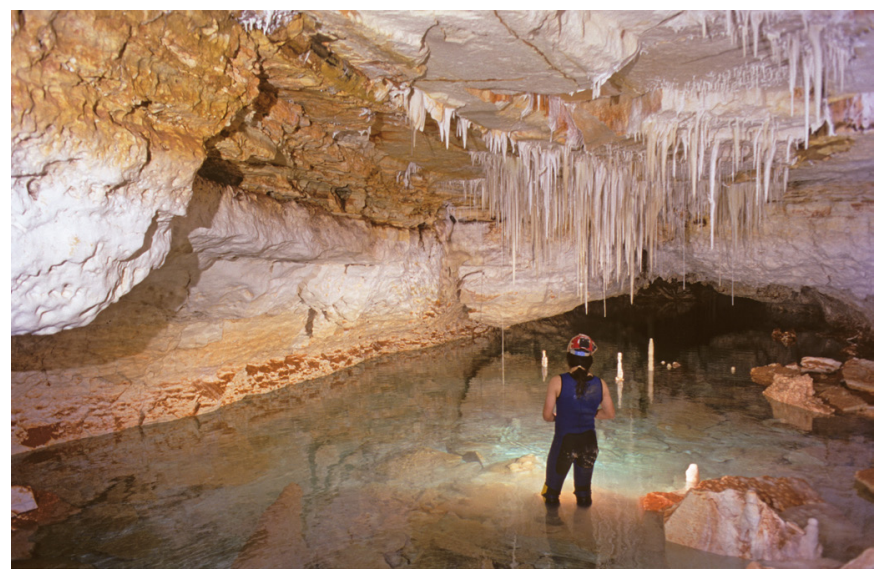

Fig. 8. Galeria del Quilòmetre, located at the Sector de Gregal, is one of the longest passages in the cave, totally flooded by phreatic brackish waters. At some spots a wide range of speleothems are present (photo by Tony Merino). southern section consists of shorter passageways extending in variable directions, being currently still explored. Finally, several aquatic breakdown chambers are scattered within this area, being only reachable by means of diving equipment; Sala Jaume Damians and Sala de la Fadrina Vella are the largest so far (Fig. 9).

\section{Sector F}

It includes a network of small interconnected passages, of an average width of $2 \mathrm{~m}$ and $3 \mathrm{~m}$ in height, normally located at the cave's upper tier. It is developed to the SW zone that lies between Sala Que No Té Nom - Galeria dels Espeleotemes and Sector del Clypeaster. In spite of the fact that this sector is above the Lower Maze of Noves Extensions, it has not been possible to link them so far. Areas with corrosion patterns alternate with others where a wide range of speleothems have been deposited. It is characterized by a maze of galleries of diverse sizes. Some sections present regular and flat floors covered by flowstones, while other joint-controlled passages are uneven and tight. In general, when the gallery is wide the floor is often level. Walls and ceiling can quite often be totally covered in moonmilk, alternatively well-decorated spots with varied speleothems also exist. Extensive

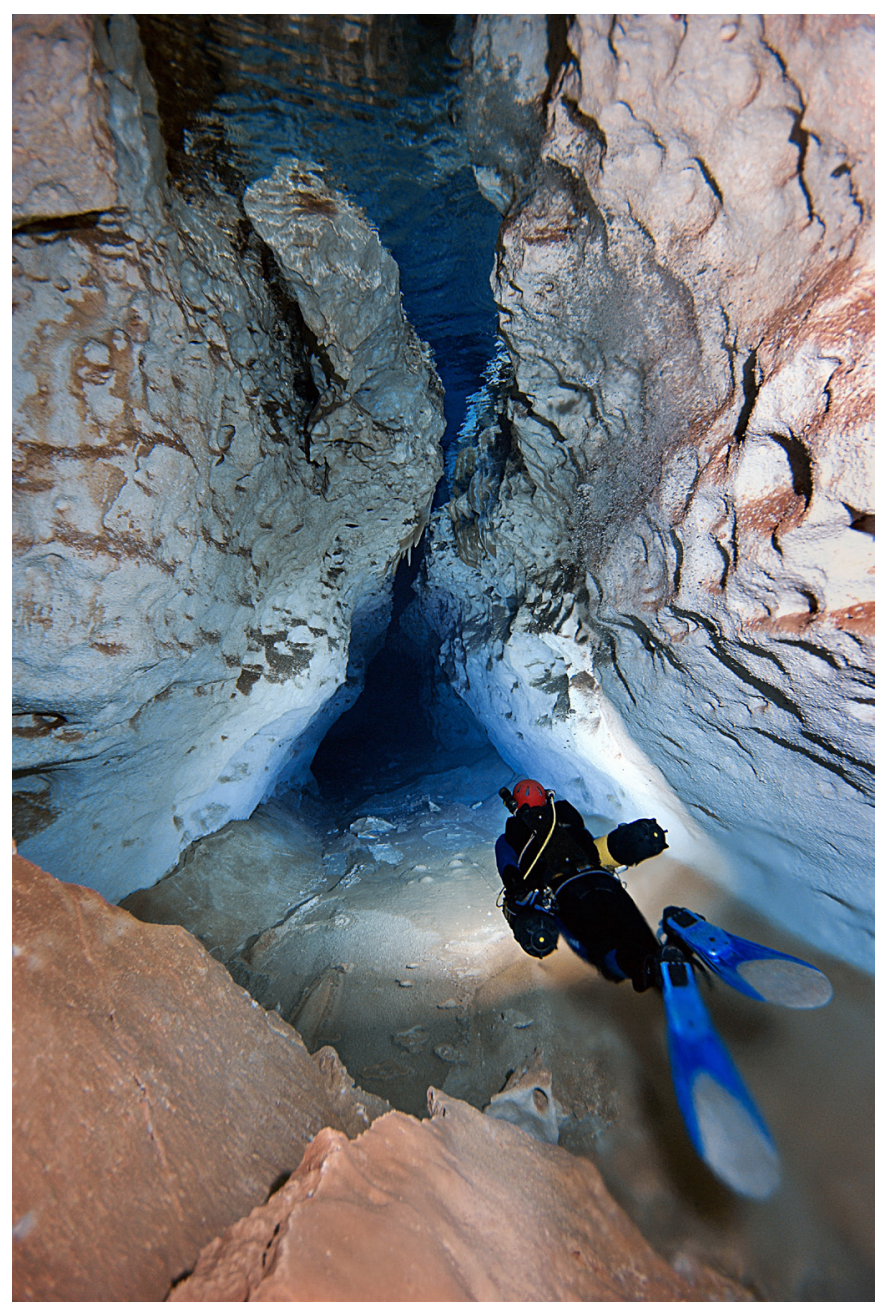

Fig. 9. Rectilinear structurally controlled passage located in the underwater extensions of Sector Subaquàtic de Gregal. Although devoid of formations, this gallery shows some corrosion morphologies in its upper section. Many of the underwater passages present a similar morphological setting to that of the upper tier of the cave (photo by Miquel Àngel Perelló). 
gours, most of them totally filled with water, are ringed with calcite crystals.

\section{Sector del Clypeaster}

This section is a network of maze-like galleries located not only at the water table, but also at the upper level that extends to the NW-most side of the cave; a variety of solutional sculpturings cover the walls, while speleothems are very few. Some mediumsized breakdown chambers are interspersed, as Sala del Compàs, Sala Fosca and Sala de la Forca. Generally, these chambers are floored with large boulders, covered with thin flowstone layers that are cracked, as a consequence of settling phenomena. Galeria Voltors must be highlighted as a paradigm of solutional passage. Galeria de les Toveres is the link passage between the northern part of Sector F (at the upper tier) and Galeria dels Clypeasters spreading near the water table. The presence of copious cave rims developed along the floor is what makes it distinctive. Galeria dels Clypeasters is a $2 \mathrm{~m}$ wide aquatic passage that stands out due to the existence of well-preserved sea urchin fossil remains that come out of its walls.

Finally, Galeria Voltors, a 500m-long passageway, utterly devoid of speleothems, is impressively affected by outstanding corrosion features (Fig. 10); the floor, roof and walls show massive spongework morphologies.

\section{Sector del Tragus}

This part of the cave is one of the most extensive and larger sectors within the Descobriments 2004 series; it is formed by an intricate maze where a set of rectilinear passages that run parallel from southwest to northeast can be distinguished. The sector is reached through the labyrinth developed to the NW area of Galeria dels Espeleotemes (Sector de les Grans Sales) and is situated both at the upper tier and the phreatic level. Some galleries are close to one kilometre in length, being structurally controlled by major joints. Galeria del Tragus and Galeria del GELL are pointed out because of their outstanding dimensions and beauty, whereas Galeria d'en Pau, Linia 200, Galeria del Gran Canyó, and Galeria de les Columnes are also worth mentioning for the beautifully decorated areas and abundance of speleothems.

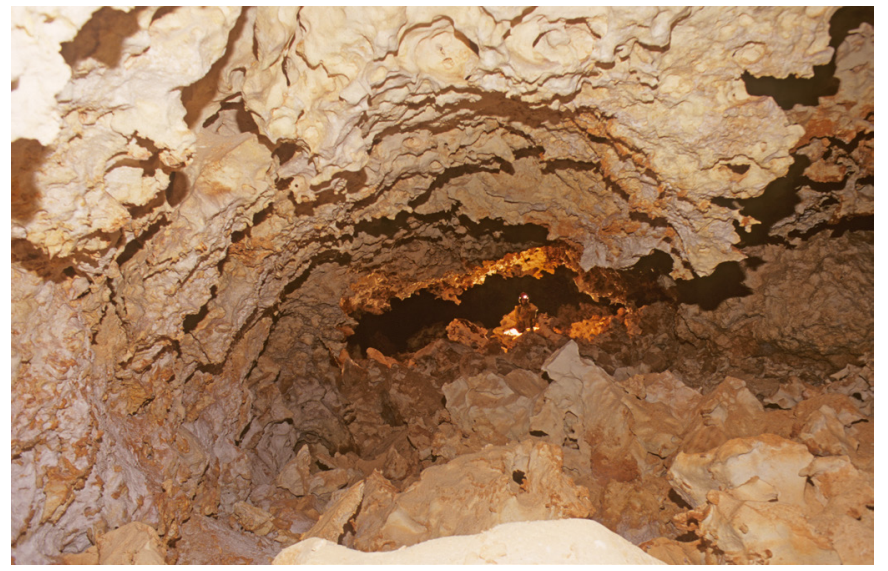

Fig. 10. Galeria de Voltors. This $500 \mathrm{~m}$ long passage is entirely covered in massive spongework that affect roof, walls and floor (photo by Tony Merino).
Galeria d'en Pau, with a total length of over $800 \mathrm{~m}$, is the connection between Sector F and Sector del Tragus, harbouring an important variety of long gours that contain significant amounts of fresh water. The heterogeneity of solutional morphologies and speleothems is quite remarkable.

On the contrary, Linia 200, presents a string of dry gours ringed with fragile crescent shelfstones. At the same time, bedding planes have been dissolved creating flat niches where various formations have been deposited.

Galeria del Gran Canyó is $600 \mathrm{~m}$ in length and can be divided into two different parts: the first one, located to the $\mathrm{NE}$, is characterized by a narrow passage floored by massive boulders, with few speleothems, those present being affected by corrosion processes; most of the walls are covered in moonmilk. The second section is situated to the SW, forming a subrectangular-shaped gallery that reaches up to $10 \mathrm{~m}$ in width and $7 \mathrm{~m}$ in height, is mostly drowned by phreatic water. A clear joint throughout the ceiling has helped the development and deposition of huge assemblages of draperies that along with long soda straws, stalactites, stalagmites and flowstones decorate the passage. Substantial accumulations of mud deposits, both at the bottom of the lake and above it, are exhibited at the furthest end of this section of Galeria del Gran Canyó.

Galeria del GELL has a length of $260 \mathrm{~m}$ and, as a consequence of mechanical readjustement processes that affect the ceiling and walls, the floor of the first third of the gallery is covered by huge breakdown boulders that extend to the middle section where the water table is reached. Finally, the last part of this passage is ornamented with a wide sort of formations and spectacular gours.

Galeria del Tragus is $930 \mathrm{~m}$ in length, being the longest in this sector and can be properly organized into two different parts. The one situated to the SW has modest dimensions, $3 \mathrm{~m}$ height and $2 \mathrm{~m}$ in width; boulders of diverse sizes are scattered along the area, as well as speleothems, some of them corroded. After a narrow and small well-decorated section, the water table is gained. At this point the square-shaped gallery increases its proportions, reaching up to $12 \mathrm{~m}$ in width and $10 \mathrm{~m}$ height, being decorated with some large stalagmites (Fig. 11). The rest of the gallery keeps its size and is floored by a significant accumulation of allochthonous mud and sand deposits that contain among others, well-preserved fossil remains of a vertebrate belonging to the Myotragus genus, an extinct goat endemic to the Mallorca and Menorca islands.

Galeria de les Columnes, is located parallel to the SE side of Galeria del Tragus. This magnificent mediumsized passage, 340 long, $20 \mathrm{~m}$ wide and $9 \mathrm{~m}$ in height, is composed of two branches. The one to the SW is floored by a large accumulation of boulders totally covered by uneven and impressive flowstones that, at the same time, are the foundations for the massive columns and stalagmites that decorate the gallery. The branch to the NE is longer and at the beginning a true speleothems forest containing gours, stalactites, stalagmites, flowstones etc, must be crossed. Then a boulders-covered section leads to a huge gour that temporarily dams up fresh water. 


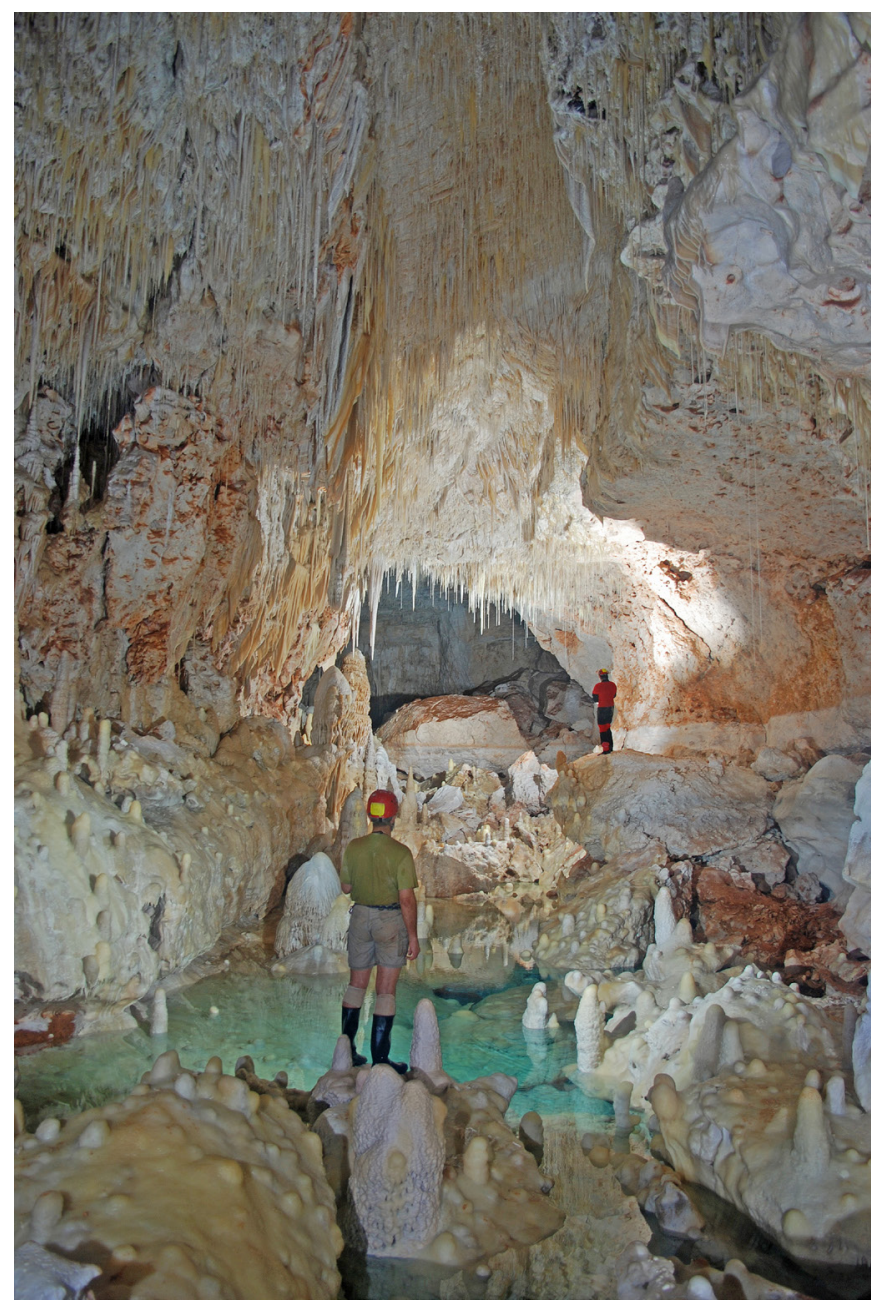

Fig. 11. Galeria del Tragus, at the section where becomes larger and the phreatic water table is reached. Former levels can be clearly seen on the right side of the picture (photo by Tony Merino).

\section{Sector Nord}

It is located to the NE of Sector del Clypeaster, being developed mainly at the upper tier. Broadly speaking, this area is characterized by tight and lowroofed galleries that form an intricate maze. It can be divided in two sections, the first one around Meandre d'en Manolo, a $250 \mathrm{~m}$ long meander passage whose walls are covered with flowstones, at the end of which the water table is reached. At the second section, Galeria del Titani must be highlighted. This $180 \mathrm{~m}$ long passage is the largest in the sector; rock beds affected by corrosion features are perfectly visible on the walls.

\section{Sector dels Privilegiats}

Finally, this underwater sector is located between the southern section of Sector Subaquàtic de Gregal and the eastern side of Sector Antic, being the area closest to the coast line. The sector starts with a large passage at shallow depth, parallel to Pista Americana; along this flooded gallery well decorated areas are interspersed with ceiling and walls covered in solutional sculpturings. The last third of this tunnel becomes more individualized, being formed by an assemblage of small-medium chambers separated by tight passages. After a notoriously narrow and small section between boulders, the main galleries of this labyrinth are reached. Generally speaking, these medium size passages are poorly decorated, the coralloids are one of the most abundant speleothems. At the same time, flat ceilings covered by massive spongeworks are succeeded by structurally controlled passages with clear fractures. The most notable dimensions are gained at junction points, with widths close to $20 \mathrm{~m}$. Galeria Negra should be emphasized due to the presence of cave rims and a large accumulation of black muddy deposits (Fig. 12). As it was mentioned, this sector approaches the current coast line but exploration was eventually thwarted at low ceiling and small passages that could not be passed.

\section{SCIENTIFIC RESEARCH}

Regarding scientific research, significant works have been performed over the last decade particularly on morphological, mineralogical, and geochronological issues (Dorale et al., 2010; Fornós et al., 2011; Ginés et al. 2009a, 2009b; Merino et al., 2009a, 2011; Tuccimei et al., 2010). Nevertheless, the potential for future in depth investigations is enormous because only the general trends are outlined in every field of research that has been undertaken.

Some of the research projects developed in the cave are conducted in collaboration with local scientific institutions, like Universitat de les Illes Balears or Institut Mediterrani d'Estudis Avançats (Fornós et al., 2010, 2011; Ginés et al., 2008, 2009a, 2009b; Merino et al., 2009a, 2009b; Merino \& Fornós, 2010a, 2010b), as well as with international researchers from foreign universities (Dorale et al., 2010; Tuccimei et al., 2010).

\section{FUTURE PROSPECTS}

It is fascinating to look at how the potential of the cave has grown within only the space of 9 years. In 2004 the cave had an extension of only $6.4 \mathrm{~km}$, and currently its length is over $74 \mathrm{~km}$. Exploration continues at a moderate pace, mainly at underwater level, but has slowed considerably since the end of 2008, when nearly every day of surveying yielded between 1 and $2 \mathrm{~km}$ of new passages.

At the upper tiers exploration and survey have been focused on Sector F, aimed at completing the survey

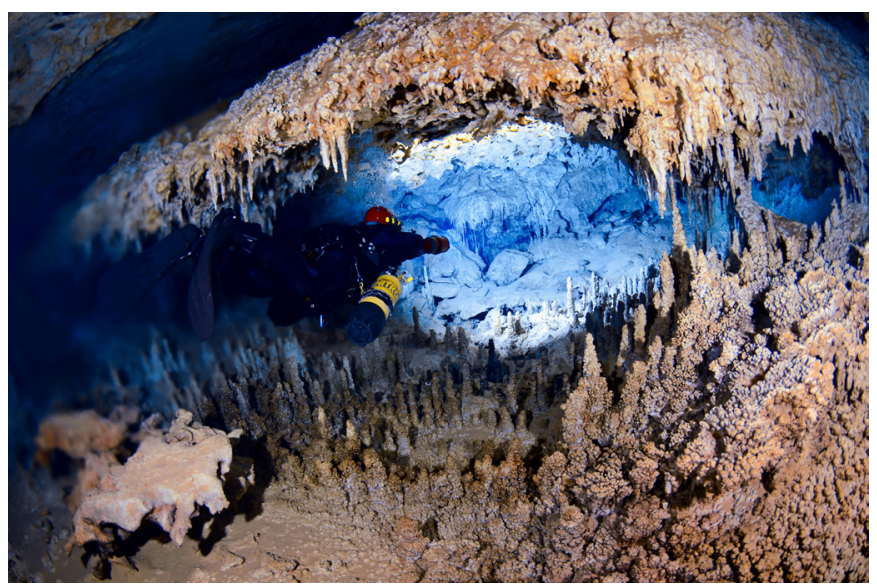

Fig. 12. Amazing gallery located at the Sector dels Privilegiats where the floor is almost totally covered by coralloids and the bellshaped ceiling shows different kind of speleothems (photo by Miquel Àngel Perelló). 
of this massive maze area. A few isolated corners may remain to be explored, but the overall extent of galleries has been realized. In addition, a particular expedition was organized to thoroughly explore Galeria Voltors, situated at the farthest northwest side of the cave. Quite surprisingly, only a few new passages were discovered. Sector Nord series offer some potential for new discoveries, since the survey is not utterly finished.

But the underwater extensions are where the cave's prospective is highly promising. Firstly, the vast Sector Subaquàtic de Gregal with its notorious passages remains partially unexplored and many galleries are due to be surveyed. Secondly, between Galeria del Quilometre and Sector de Gregal a fresh challenging area of underwater passages is being explored. Some of the narrow and small passages are negotiated with the aim of trying to reach the void area existing towards the northwestern side of the cave (Sector del Tragus). Besides, a new and extremely demanding series of subaquatic galleries have been discovered at Gran Canyó area, where cave divers require the logistic support of other cavers to haul the bulky diving equipment. Finally, no further exploration prospects seem to exist at the subaquatic maze located to the southern and eastern side of Pista Americana (Sector dels Privilegiats), where exploration has been taken to the accessible limits.

Given the intricacies and complexity of the cave, there is every chance that a continued effort and dedication will undoubtedly reveal new discoveries, both in the upper passages and close to the phreatic level as well as along the underwater extensions.

\section{CAVE PROTECTION}

The cave is under the protection of Conselleria de Medi Ambient, Govern Balear (the Regional Authority). In July 2000 it was listed as Area of Community Interest by the Govern de les Illes Balears (the Regional Authority), and in March 2006 was declared and registered with code ES5310049, belonging to the Natura 2000 Network (Council Directive, 92/43EEC).

Since the latter date, the Regional Authority had 6 years to work out a Management Plan and submit it to the ECC. This document should be drawn up in order to establish targets and management guidelines not only for the cave, but also for the territorial boundaries where it lies. In case of having been approved, the legal entity of Area of Community Interest would have been changed to Special Conservation Zone. Subsequently, and thanks to the efforts made by the Federació Balear d'Espeleologia and the Conselleria de Medi Ambient, on March 11, 2011, an Agreement of the Regional Council was published with the aim of starting the procedure to declare the cave a Natural Monument. Due to diverse problems and political changes of the regional governments, neither the natural monument, nor the management plan have been accomplished. Nevertheless, since 2007, the Federacio Balear d'Espeleologia, along with the Universitat de les Illes Balears, have made all possible effort to help working out the project. Currently, the only protective measures officially taken are the already mentioned declaration of Area of Community Interest and the installation and maintenance of a gate and alarm system. In the light of the results of this situation, a massive effort should be made to fulfill the comprehensive protection project.

\section{ACKNOWLEDGEMENTS}

The authors are deeply grateful to the numerous cavers who worked with us during the exploration, surveying, and study of the cave, such a great task would not have been possible without their encouragement, hard work and motivation. We also must thank the people from the Conselleria de Medi Ambient (Regional Authority) not only for granting the permits to explore the cave, but also for their support. Grateful acknowledgment is made to Magi Clar for sharing with us the first photos taking in the cave. Special thanks to Joaquin Ginés for his bright ideas and his willingness to review this manuscript. Part of his work was supported by the research fund of MINECO Project CGL2010-18616/ BTE of the Spanish Government.

\section{REFERENCES}

Collignon M., 1982 - Une première des spéléos namurois a Majorque (Espagne). Au Royaume d'Hades. Groupe Spéléo Namur-Ciney, 2: 15-26.

Dorale J.A., Onac B.P., Fornós J.J., Ginés J., Ginés A., Tuccimei P. \& Peate D.W., 2010 - Sea level highstand 81,000 years ago in Mallorca. Science, 327: 860-863. http://dx.doi.org/10.1126/science.1181725

Fornós J.J., Ginés J., Merino A. \& Bover P., 2010 - El rebliment sedimentari de la galeria del Tragus a la cova des Pas de Vallgornera (Llucmajor, Mallorca). Bolletí de la Societat d'Història Natural de les Balears, 53: 179-191.

Fornós J.J., Merino A., Ginés J., Ginés A. \& Gràcia F., 2011 - Solutional features and cave deposits related to hypogene speleogenetic processes in a littoral cave of Mallorca Island (western Mediterranean). Carbonates and Evaporites, 26 (1): 69-81. http://dx.doi.org/10.1007/s13146-010-0040-3

Ginés J., Ginés A., Fornós J.J., Gràcia F., \& Merino A., 2008 - Noves observacions sobre l'espeleogènesi en el Migjorn de Mallorca: els condicionants litològics en alguns grans sistemes subterranis litorals. Endins, 32: 49-79.

Ginés J., Ginés A., Fornós J.J., Merino A. \&. Gràcia F., 2009a - On the role of hypogene speleogenesis in shaping the coastal endokarst of southern Mallorca (Western Mediterranean). In: Klimchouk A.B. \& Ford D.C. (Eds.), Hypogene speleogenesis and karst hydrogeology of artesian basins. Simferopol, Ukrania: Ukrainian Institute of Speleology and Karstology, Special Paper 1: 91-99.

Ginés J., Ginés A., Fornós J.J., Merino A. \&. Gràcia F., $2009 \mathrm{~b}$ - About the genesis of an exceptional coastal cave from Mallorca Island (Western Mediterranean). The lithological control over the pattern and morphology of Cova des Pas de Vallgornera. In White, W.B. (Ed.), Proceedings of the $15^{\text {th }}$ International Congress of Speleology, Kerrville, USA, 1: 481-487.

Gràcia F., Fornós J.J., Gamundí P., Clamor B., Pocoví J. \& Perelló M.A., 2009 - Les descobertes subaquàtiques a la Cova des Pas de Vallgornera (Llucmajor, Mallorca): Història $i$ descripció dels descobriments, hidrologia, espeleotemes, sediments, paleontología i fauna. Endins, 33: 35-72. 
Merino A., 1993 - La Cova des Pas de Vallgornera. Endins, 19: 17-23.

Merino A., 2000 - Nuevas extensiones de la Cova des Pas de Vallgornera (Llucmajor, Mallorca). Endins, 23: 7-21.

Merino A. \& Fornós J.J., 2010a - Los conjuntos morfológicos de flujo ascendente (Morphological Suite of Rising Flow) en la Cova des Pas de Vallgornera (Llucmajor, Mallorca). Endins, 34: 87-102.

Merino A. \& Fornós J.J., 2010b - Presencia de Pool Fingers y U-loops en la Cova des Pas de Vallgornera (Mallorca, España). Endins, 34: 103-107.

Merino A., Fornós J.J. \& Onac B.P., 2009a - Preliminary data on mineralogical aspects of cave rims and vents in Cova des Pas de Vallgornera, Mallorca. In White, W.B. (Ed.), Proceedings of the $15^{\text {th }}$ International Congress of Speleology, Kerrville, USA, 1: 307-311.

Merino A., Fornós J.J. \& Onac B.P., 2009b - Datos preliminares sobre la mineralogía de los precipitados asociados a los respiraderos y toberas existentes en la Cova des Pas de Vallgornera (Mallorca). Endins, 33: 99-104.

Merino A., Mulet A. \& Mulet G., 2006 - La Cova des Pas de Vallgornera: 23 kilómetros de desarrollo topografiado (Llucmajor, Mallorca). Endins, 30: 29-48.
Merino A., Mulet A., Mulet G., Croix A. \& Gràcia F., 2007 - La Cova des Pas de Vallgornera (Llucmajor, Mallorca): 40 kilómetros de desarrollo topografiado. Endins, 31: 101-110.

Merino A., Mulet A., Mulet G., Croix A. \& Gràcia F., 2008 - La Cova des Pas de Vallgornera (Llucmajor, Mallorca): Alcanza los 55 kilómetros de desarrollo topográfico. Endins, 32: 33-42.

Merino A., Mulet A., Mulet G., Croix A. \& Gràcia F., 2009 - Cova des Pas de Vallgornera: an exceptional litoral cave from Mallorca Island (Spain). In White, W.B. (Ed.), Proceedings of the $15^{\text {th }}$ International Congress of Speleology, Kerrville, USA, 1: 522-527.

Merino A., Mulet A., Mulet G., Croix A., Kristofersson A., Gràcia F., Ginés J. \& Fornós J.J., 2011 - La Cova des Pas de Vallgornera (Llucmajor, Mallorca). La cova de major desenvolupament de les Illes Balears. Endins, 35 / Monografies de la Societat d'Història Natural de les Balears 17: 147-164.

Tuccimei P., Soligo M., Ginés J., Ginés A., Fornós J.J., Kramers J. \& Villa I.M., 2010 - Constraining Holocene sea levels using U-Th ages of phreatic overgrowths on speleothems from coastal caves in Mallorca (Western Mediterranean). Earth Surface Processes and Landforms, 35 (7): 782-790. 